\title{
Study of typology and morphology of stupa variety at the Padepokan Dhammadipa Ārāma in Malang East Java
}

\author{
Ferlina Sugata ${ }^{*}$, Venny ${ }^{2}$ \\ Faculty of Arts and Design, Maranatha Christian University, Bandung, Indonesia
}

\begin{abstract}
Religious people generally have a symbol of respect to worship the greatness of role models in their respective religions. This is motivated by different traditions, history, locations, and developments of religion and worship activities that affect the emergence of various types and forms of worship. One of them is a building named stupa. The stupa building as a means of worship accommodates worship activities in Buddhism. The stupa also functions as an object of respect in implementing worship. Padepokan Dhammadipa Ārāma's premises in Malang are architectural stupas buildings similar to the Patirupaka Stupa Shwedagon in Myanmar. Therefore, this study aims to determine the extent to which this replication process occurs in terms of typological and morphological studies, to analyze typology by classifying stupas based on the types of stupas in the world where each culture has its characteristics, and to analyze morphology based on the level of change and tendency of change. The method of this study is a qualitative study with a rationalistic approach. The study results are tabulations of typology and morphology of stupa architecture as a guide for the types and forms of stupa architecture, contributing to the science of Buddhist religious architecture in the Indonesian Archipelago.
\end{abstract}

ARTICLE INFO

\section{Keywords:}

Patirupaka, stupa,

morphology, typology, replica

\section{Article History:}

Received: Nov 27th, 2021

Revised: Dec 23rd, 2021

Accepted: Dec 23rd, 2021

Published: Dec 30 th 2021

How to Cite in APA Style: Sugata, F. \& Venny. (2021). Study of typology and morphology of stupa variety at the Padepokan Dhammadipa Ārāma in Malang East Java. Smaratungga: Journal of Education and Buddhist Studies, 1(2), 23-36. doi: $10.53417 /$ sjebs.v1i2.53

\section{Introduction}

There are a variety of architectural buildings that have a religious identity for Buddhists. One of them is the stupa building as a means of worship for Buddhists, and worship is a form of respect in Buddhist beliefs that generally accommodates worship activities. This worship building can still be differentiated according to its function and the scale of the building. The worship building studied as the object of study is a worship service building in the form of a stupa building. This limitation is based on the development of religious architecture, especially the stupa architecture, which has undergone various modifications with physical and cognate forms. The result is that the stupa as a more original building will be studied in this study. In more detail, the building taken as the object of study is the stupa building

*Corresponding author: ferlina.sugata@art.maranatha.edu

Published by Center of Research and Publication of Smaratungga Buddhist Collage

This is an open access article under the CC BY-NC 4.0 (https://creativecommons.org/licenses/by-nc/4.0/) https://doi.org/10.53417/sjebs.v1i2.53 
with a shape that did not undergo a crucial shape transformation, especially in Southeast Asian countries. In contrast, in subsequent developments due to the influence of culture, architecture, and art, the shape of this stupa can become a popular form of pagoda born in Central Asian countries such as China, Japan, and Korea.

According to their function in developing Buddhist religious architecture, there are two types of architecture. The first is the type of architecture that functions to accommodate various needs in religious life, such as the need to perform worship services, a place to put objects of respect, a library or as a residence for members of the Sangha; and the second is the type of architecture that functions as an object of respect and worship itself.

This first type of architecture can be ārāma, vihāra, or cetiya buildings, while the second type is usually a stupa or pagoda. In a large ārāma or vihāra complex, a stupa architecture often becomes the focal point of the entire building in the complex. It will also be found in the Padepokan Dhammadipa Ārāma in Malang, where the complex's stupa is the focal point.

The chosen object of study at the Padepokan Dharmadipa Ārāma in Malang is the architecture of the stupa building, which is the first Shwedagon Patirupaka Stupa in Indonesia. The shape of the stupa used at the Padepokan Dhammadipa Ārāma is a replica of the Shwedagon stupa in Myanmar. And, the Patirupaka Stupa Shwedagon is also found in Berastagi, North Sumatra. This study extends to the replication process in typological and morphological studies to analyze typology by classifying stupas based on the types of stupas in the world where each culture has its characteristics and to analyze its morphology based on the level and the tendency of change. The rationale of the Patirupaka Shwedagon Stupa in Myanmar or making replicas of stupas from other countries and building them in Indonesia encourages the authors to study the replication process in terms of typology and morphology.

\section{Method}

The research method used is a rationalistic qualitative method with a rationalistic approach through descriptive explanations. Furthermore, Hameed (2020) explains that the rationalistic qualitative research method is based on an intellectual understanding with the ability to argue logically and is supported by relevant data. It is slightly different from phenomenology, whose objects are living, so observing the phenomenon takes a relatively long time.

Observations are done by considering the typological and morphological variables. Typology and morphology mean a series of analytical processes by classifying architectural objects into various forms. This typology is used for morphological analysis by paying attention to changes in objects, both small, medium, and significant changes. The variables in this study are based on the typology of the micro side, which is the building elements. The morphological variables are history, form, function, and change intensity.

The data collection techniques include literary study, field study, interview, and data analysis. The literary study is intended as a research guide for the theory of architecture and design in the study of form and space and the development of religious history because the study is processing qualitative data. The field study is a direct study of the study object, intended to make comparisons through the object 
of study to appreciate reality to become more accurate. The interview is done in qualitative data as not entirely contained in the literature review. Hence, non-library sources are also needed since data on the development of Buddhist religion comes from non-written sources, especially regarding culture and history. Moreover, the data analysis is carried out evaluatively with writing and graphics to show the description and formation of architectural physical elements and descriptions of their activities.

\section{Findings}

\section{History and development of Padepokan Dhammadipa Ārāma}

The establishment of the Padepokan Dhammadipa Ārāma began with a monk from Southern Thailand named Phra Kru Atthacariyarukich or commonly known as Bhante Win, in May 1970. He had noble ideas to establish a proper place of worship for Buddhists, particularly in Malang and surrounding areas. Buddhists welcomed these noble ideals with joy in the Malang and Surabaya areas. To realize this goal, Bhante Win collected funds from donors. At that time, Ven. Somdet Phra Nanasamvara also handed over funds amounting to Rp202,240.00, and it was used to buy the land where the Padepokan Dhammadipa Ārāma was built.

On July 5, 1971, three people were appointed as holders of the people's mandate, namely Bhikkhu Agga Jinamitto, Mr. Djamal Bakir, and Mrs. Pandit Sri Hartini, who bought land in Ngandat Hamlet, Mojorejo Village, Junrejo Subdistrict, Batu City, which covered an area of 4,400 m2, from Mr. Dasuki for Rp. 75.00 per m². After that, a development committee was formed, and it was handled directly by the Young Pandita Sri Hartini Dharmaniyani Djamal Bakir. On August 15, 1971, the erection of the first pillar of the Veluvana building began as the first Dhammasālā. It was named Veluvana because the main building was made entirely of bamboo, except the roof and floor. On September 25, 1971, this vihāra was visited by the head of the World Fellowship of Buddhist (WFB), Princess Poon Pismai Diskul of Thailand. He gave a gift of a Buddha statue as high as $\pm 40 \mathrm{~cm}$. On that day, the inauguration ceremony of Padepokan Veluvana was also held and attended by Mahā Nāyaka Sangha Indonesia, Ven. Sthavira Ashin Jinarakhita.

In 1992, kuțis were built for monks and devotees to practice vipassanā began to be built. The dominance of the building used ironwood/ulin wood material with the result that it can last a long time, even up to hundreds of years. In 1995, the Bhāvanā Sabhā as for a place for vipassanā meditation was built. Two years later, the uposathagāra, used to ordain novices as monks, was built. In addition, a reclining Buddha, a form or attitude of meditation carried out by the Buddha before he reached parinibbāna, was also built. There was also a balekambang, an open area near a lotus pond used for various activities such as meetings, discussions, and meditation built in 1997.

Then, in 2000, the Dhammadipa Ārāma Foundation established a campus of the Kertarajasa Batu Buddhist College or Sekolah Tinggi Agama Buddha (STAB) Kertarajasa Batu. The establishment of this STAB had received operational permits and inauguration from the Directorate General of Hindu and Buddhist Community 
Guidance, Ministry of Religion of the Republic of Indonesia, and the Mahā Nāyaka of Sangha Theravada Indonesia, Ven. Sri Pannavaro Mahathera, on October 23, 2000. The following year, on the idea of Ven. Khanthidaro, the Dhammadasa underground museum, and Patirupaka Shwedagon Pagoda were built. Inside this museum, there are several rooms, including a library; a sangha meeting room; a Dhammadipa Ārāma room; a Myanmar, China, Sri Lanka, Thailand room; an international room; an interregional room; a relic room; a photo room for Buddhist temples; and a Dhammadipa Ârāma pioneer room.

The Patirupaka Shwedagon Pagoda is a symbol of the splendor of the Padepokan Dhammadipa Ârāma. The pagoda is a replica of the Shwedagon Pagoda in Myanmar. The pagoda is the first pagoda building in Indonesia and has won an award from the Indonesian World Record Museum or Museum Rekor Dunia Indonesia (MURI). In 2005, the Padepokan Dhammadipa made several further developments, including building the Dhammasālā Lumbini, a room for praying and meditation. In the following year, the Kertarajasa Graha was built. It functioned as a hall, a place for seminars, public lectures, a girls' dormitory, a stock exchange, a car garage, the Kalama Sutta monument, the Ashoka inscription, and others. All of these developments encouraged the growth of Padepokan Dhammadipa Ārāma. The Padepokan Dhammadipa Ārāma was designed by a volunteer architect named Ir. Shelly Gunavati Wardojo MBA, MM, MT from Surabaya.

\section{Facilities and infrastructure at the Padepokan Dhammadipa Ārāma Complex}

The Padepokan Dhammadipa Ārāma was built as a complete Buddhist worship facility for Malang and its surroundings. Therefore, this hermitage (padepokan) complex has various rooms with leading and supporting functions, including:

\section{Uposathagāra}

It is a building that functions to carry out monkhood ceremonies such as the upasamadā or ordination ceremony, the patimokkha ceremony, and others.

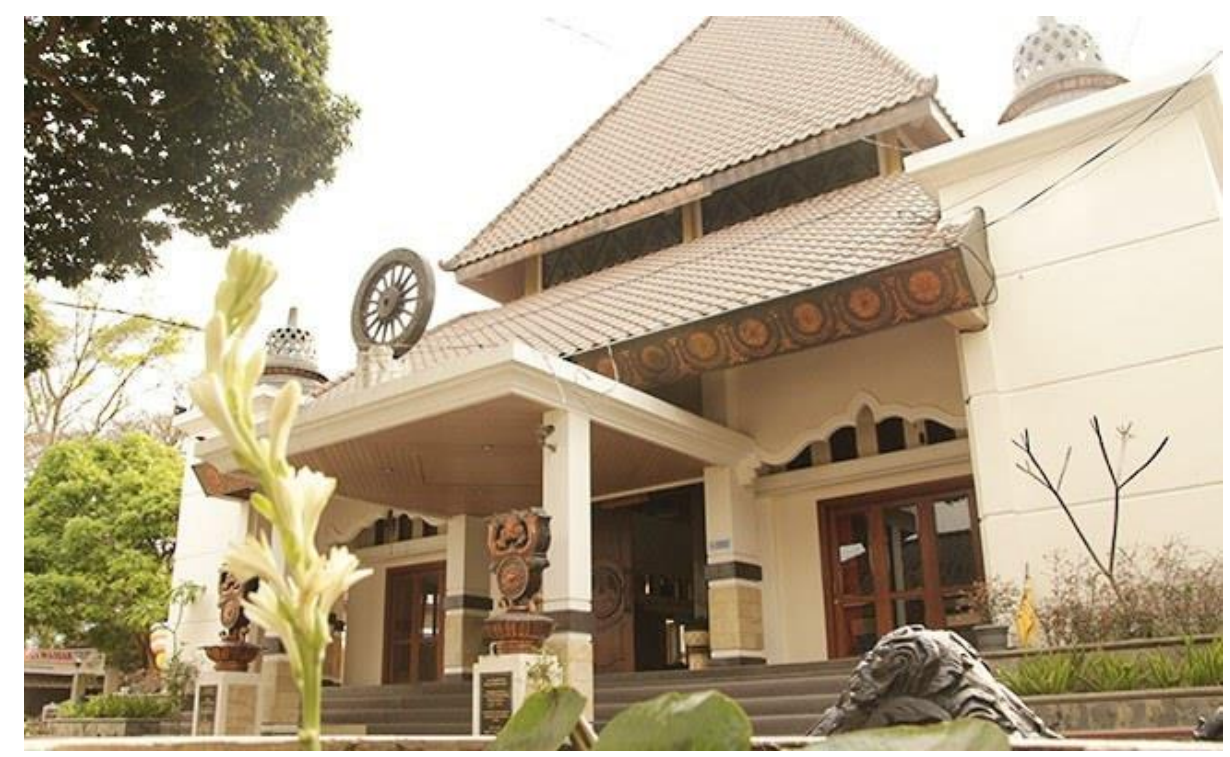

Figure. 1 Uposathagāra (Source: www.buddhazine.com) 


\section{Patirupaka Shwedagon Building}

The Patirupaka Shwedagon Building is what turns out to be a replica of Patirupaka Shwedagon from Myanmar, which functioned as a place to store relics. It is located at the back of the hermitage, close to Dhammasālā. Apart from adopting the original stupa form in Myanmar, this stupa building also has Indonesian elements, especially the Jawi Temple in East Java, which is applied to the elements of the gate of the building. A chinte (tiger) at the stairs as a guard equipped with a bell that sounded before guests entered the building. This stupa building got a MURI record with a record number of 1,038.

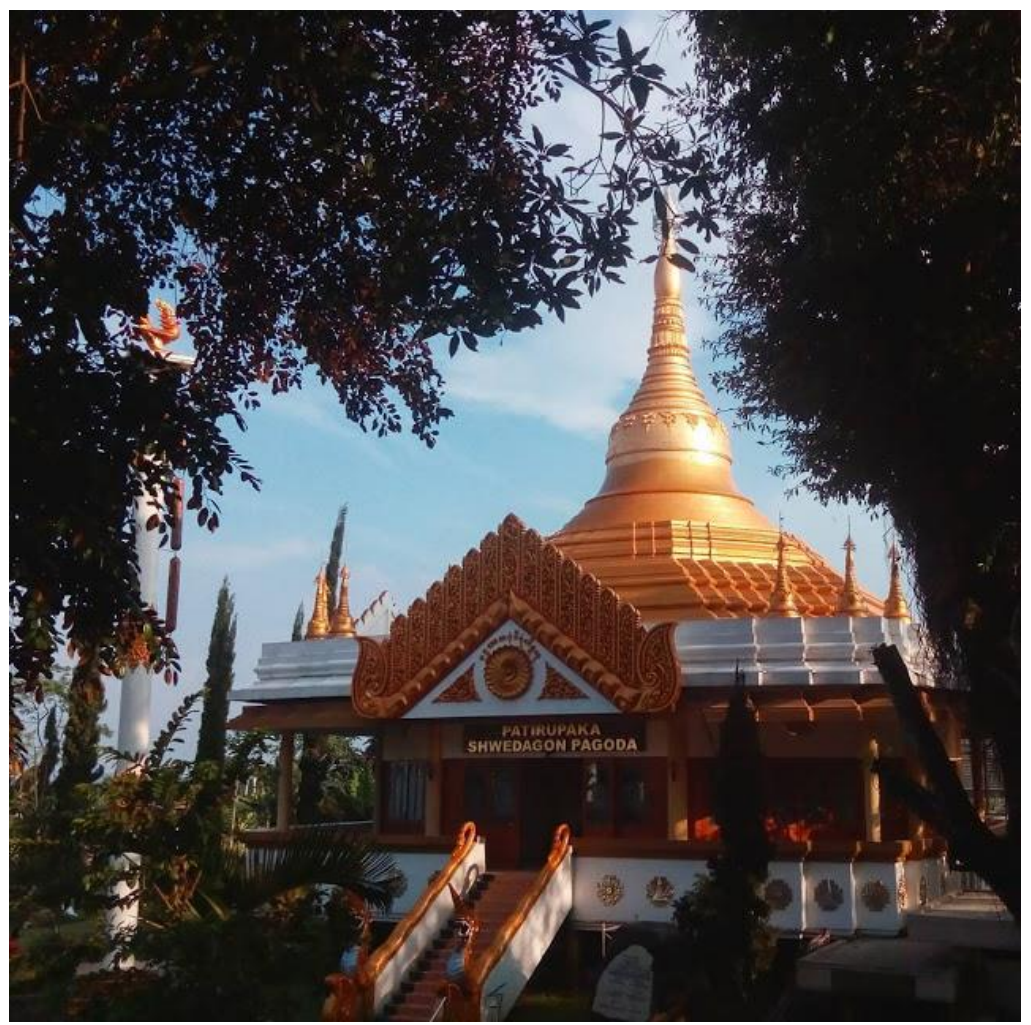

Figure.2 Replica of Patirupaka Shwedagon Stupa (Source: www.photomalang.com)

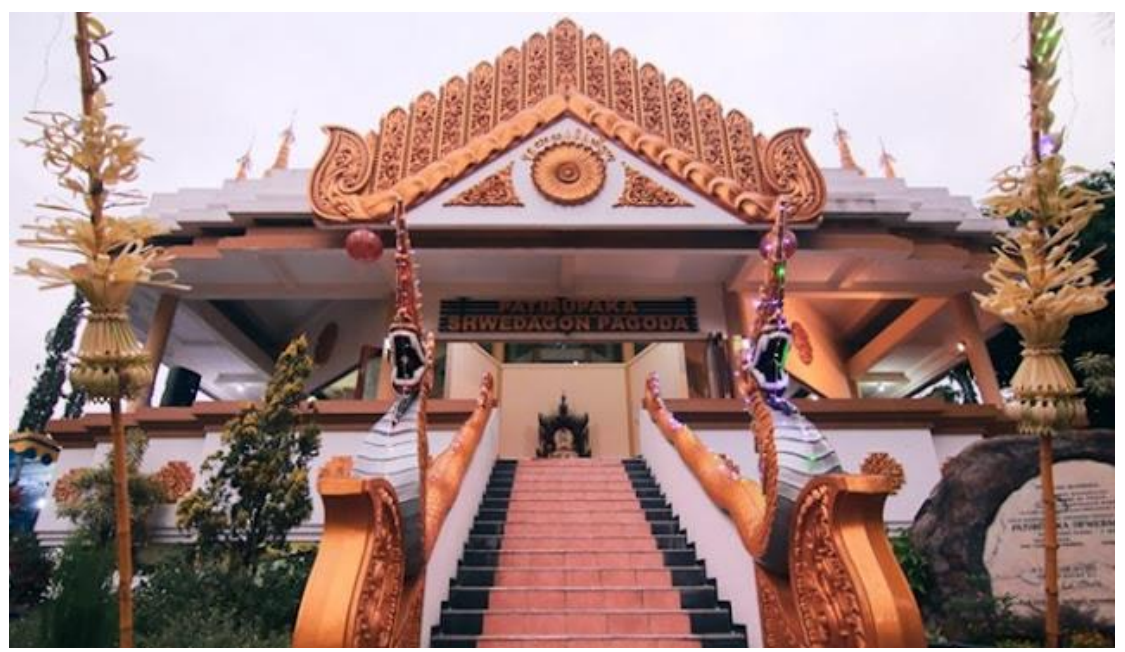

Figure. 3 Entrance Elements of the Replica of Shwedagon Patirupaka Stupa Building

(Source: www.cahayamalam.com) 


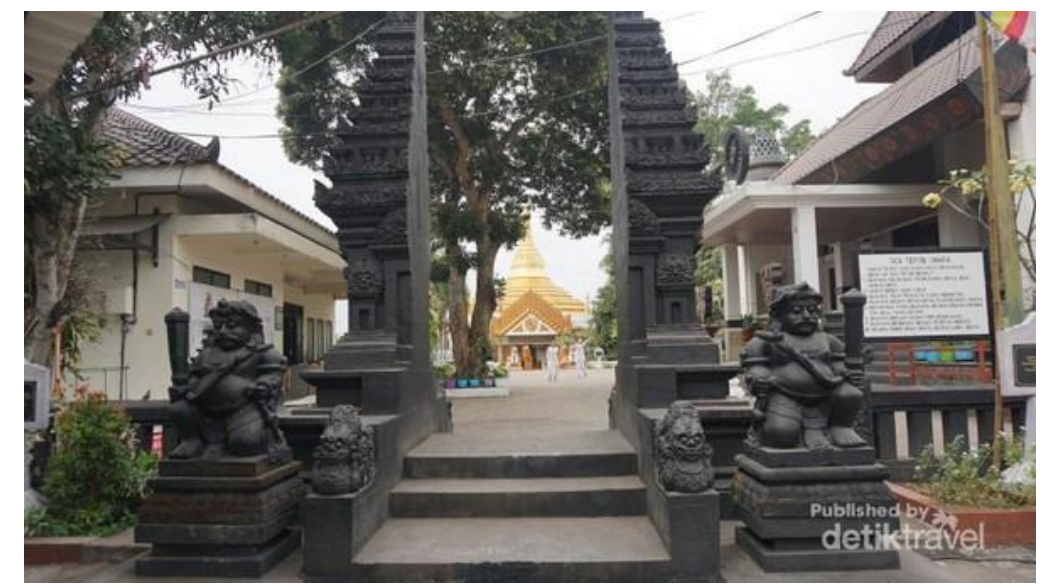

Figure. 4 Elements of the Jawi Temple Gate of the Replica Shwedagon Patirupaka Stupa Building (Source: www.travel.detik.com)

\section{Dhammasālā Lumbini and Veluvana}

Dhammasālā Lumbini is a space that functions as a place for worship, meditation, and discussion of Buddha's teachings or Dhamma. This room is partitioned, and hence if needed, it can be used with a capacity of up to 300 people. This space was inaugurated in 2007. At the front of the building, there is an element of the Tiratana or Triratna symbol, which symbolizes the Three Jewels: Buddha, Dhamma, and Sañgha.

Meanwhile, Dhammasālā Veluvana is the first Dhammasālā built-in 1976, which has undergone a renovation process. The architecture of Dhammasālā Veluvana is octagonal. The octagon represents the noble eightfold path. Meanwhile, Dhammasālā Veluvana is the first Dhammasālā built-in 1976, which has undergone a renovation process. The architecture of Dhammasālā Veluvana is octagonal. The octagon represents the noble eightfold path.

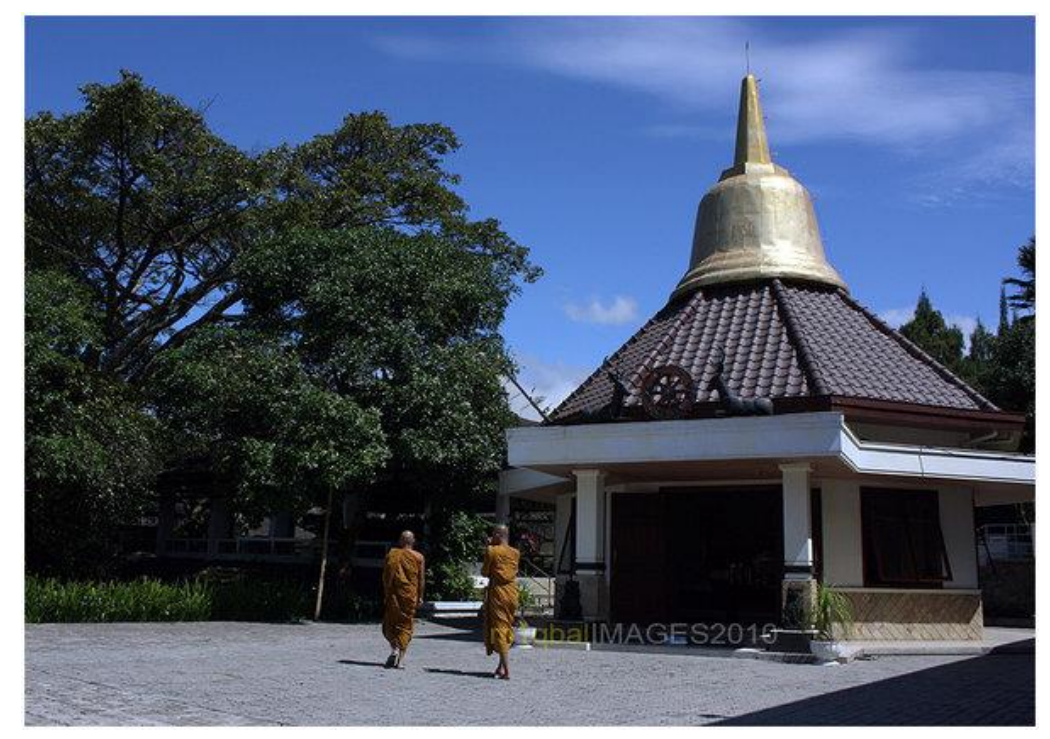

Figure. 5 Octagonal Shape of the Dhammasālā Veluvana Building (Source: www.buddhazine.com) 


\section{Dhammadasa Museum}

The meaning of the word Dhammadasa is the mirror of the Dhamma (Buddha's teachings). It can be interpreted that anyone who visits this museum can reflect on the teachings of the Dhamma from what they see, read, or hear while entering the museum area. The hope is that when they leave this museum, visitors will gain valuable knowledge about the Dhamma of Buddha's teachings. This museum is a place to visually recall how Buddha conveyed his great teachings.

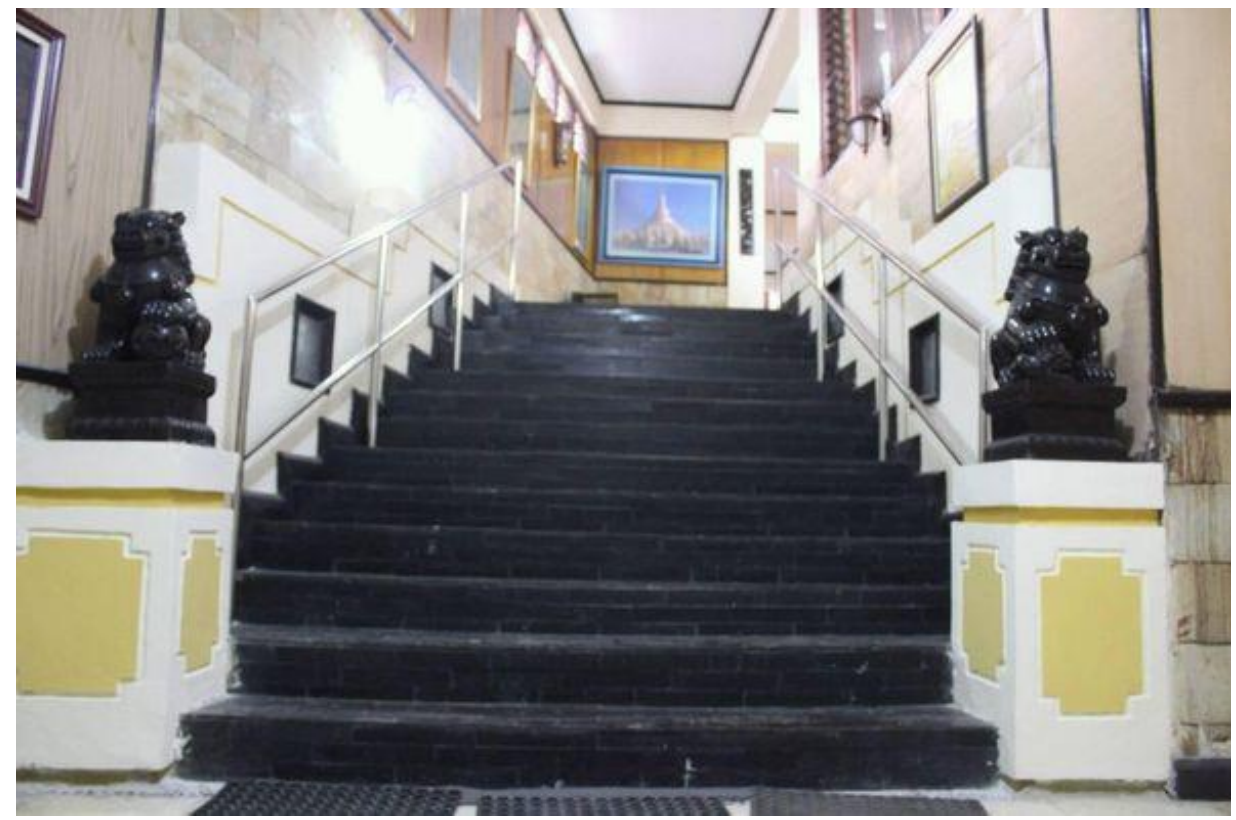

Figure. 6 Dhammadasa Museum Hallway (Source: Facebook Dhammadipa Ārāma)

\section{Anekadhippaya Sabhā (Balekambang)}

It is a multifunctional open space above a pool used for various activities, such as seminars, meetings, meditations, Dhamma discussions, and other activities.

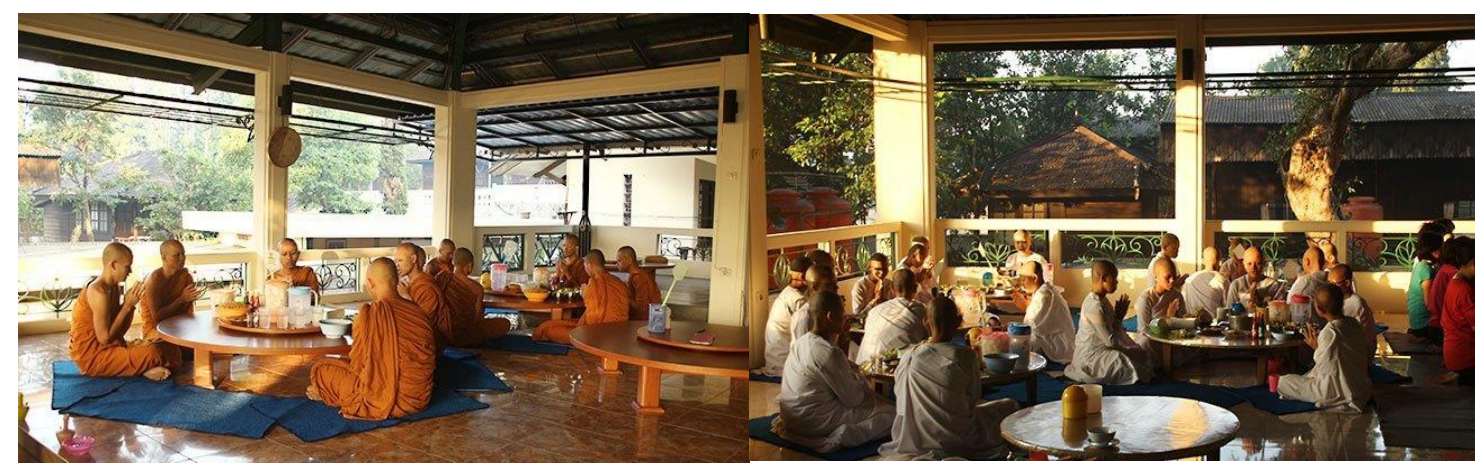

Fig. 7 Balekambang (Source: www.buddhazine.com)

\section{Bhāvanā Sabhā}

It is a particular room used to develop a spiritual mind, especially vipassana $\bar{a}$ bhāvanā. 
Kuți

It is a residence for monks and devotees of vipassanā practice. All of the kuti buildings are constructed of ironwood to avoid termites and moisture because the quality of ironwood is very high, and hence it can last hundreds of years. In addition, it can also respond to cold weather since the Padepokan Dhammadipa Ārāma is located at the foot of the mountain and is a highland.

\section{Bodhi Plaza}

It is an altar of Buddha statues shaded by the Bodhi Tree. The Bodhi Tree at this hermitage is a descendant of the Bodhi Tree in Bodhgaya, India, where the ascetic Gautama attained perfect enlightenment and became Sammā Sambudha.

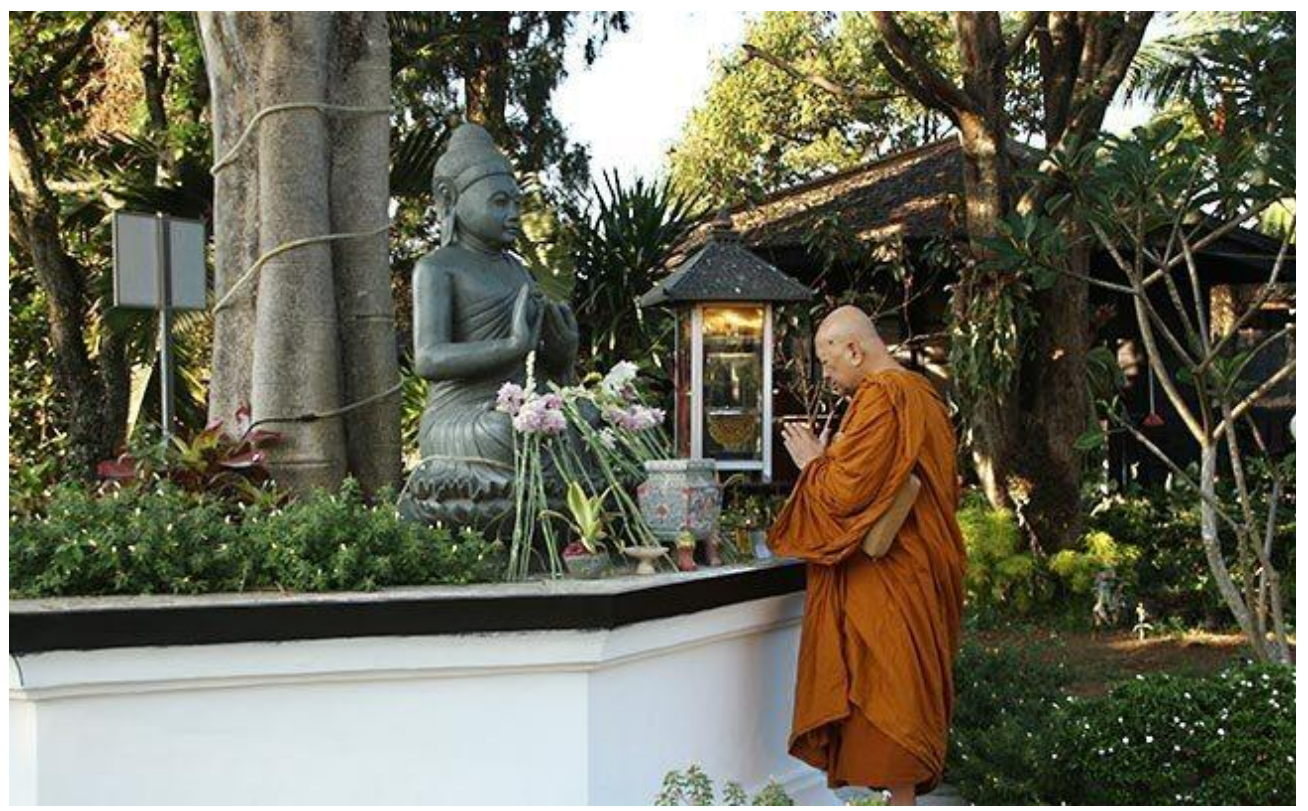

Fig. 8 Bodhi Plaza (Source: www.buddhazine.com)

Inscription of King Asoka (270-230 M)

It is a replica of the Asoka Pillar inscription from India, a symbol of religious tolerance that reads, "Whoever wants to glorify his religion by criticizing other religions, it will be very detrimental to his religion and also detrimental to the development of other religions. Therefore, tolerance and harmony are highly recommended, and hence there will be peace, tranquility, and peace in society".

\section{Discussion}

\section{Typo-morphological analysis of the Patirupaka Shwedagon Stupa at Padepokan Dhammadipa Ârāma Malang reviewed based on the history of the stupa construction}

The stupa in the Padepokan Dhammadipa Ārāma complex in Malang adopts the form of the original Shwedagon stupa in Myanmar. The function of this building is as a place to store relics. 


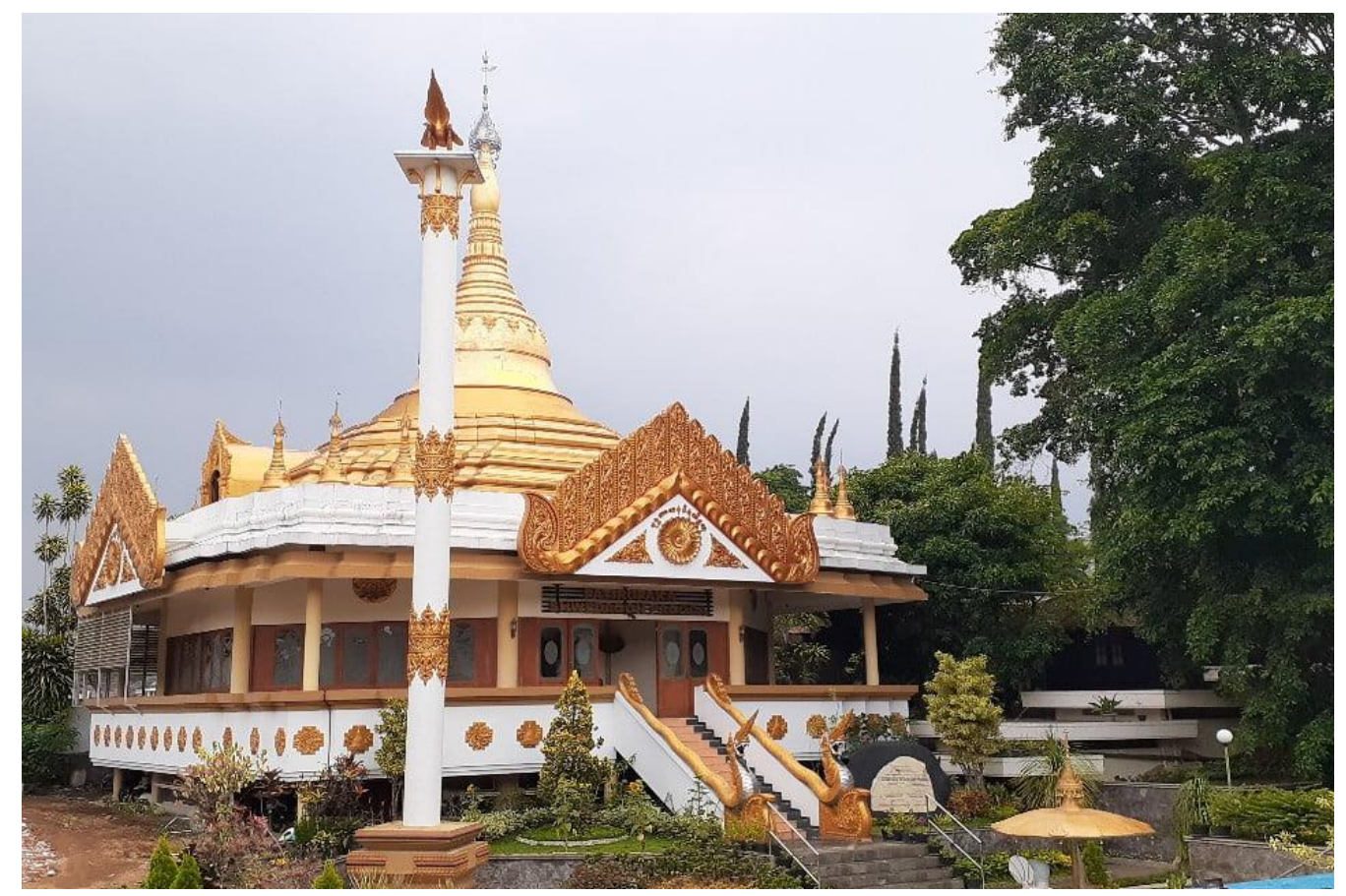

Fig. 9 Stupa Building Replica of Patirupaka Shwedagon and Ashoka Pillars (Source: www.photomalang.com)

Known as the Shwedagon Pagoda, this building is a stupa building like a temple complex in Indonesia. It is commonly called Shwedagon Zedi Daw in English and is very familiar with the term Golden Pagoda. This building is a 98 meters high, gold-plated stupa located in Yangon, Myanmar, precisely at the west of Lake Kandawgyi, the Singuttara hills, and dominates the cityscape of Yangon. This stupa is considered the most sacred for the Burmese because it contains relics of the original Buddha's past, including Kakusandha's staff, Konagamana water filter, a piece of Kassapa's robe, and eight strands of Siddhartha Gautama's hair.

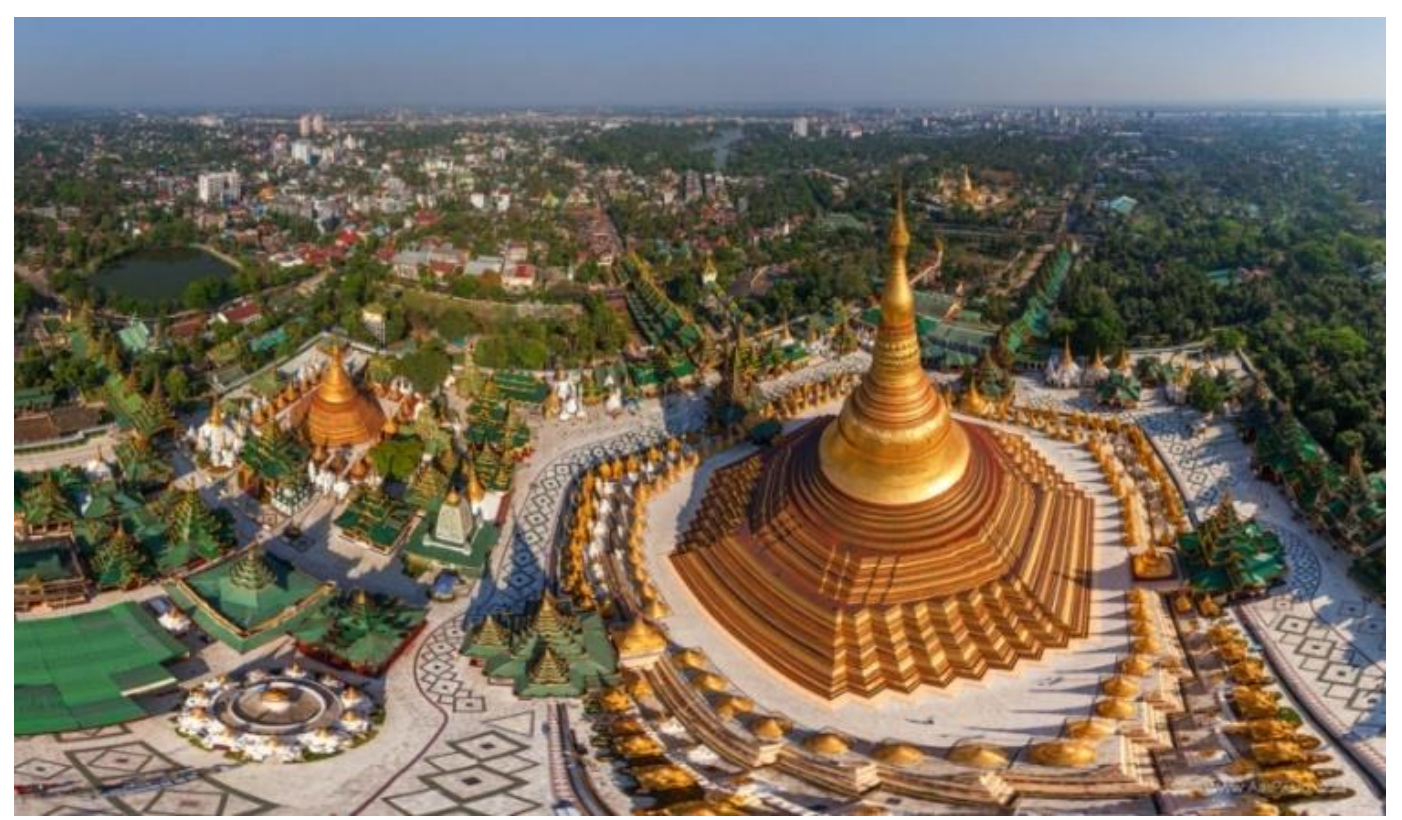

Figure. 10 Myanmar's Shwedagon Stupa (Source: www.shwedagonpagoda.com) 


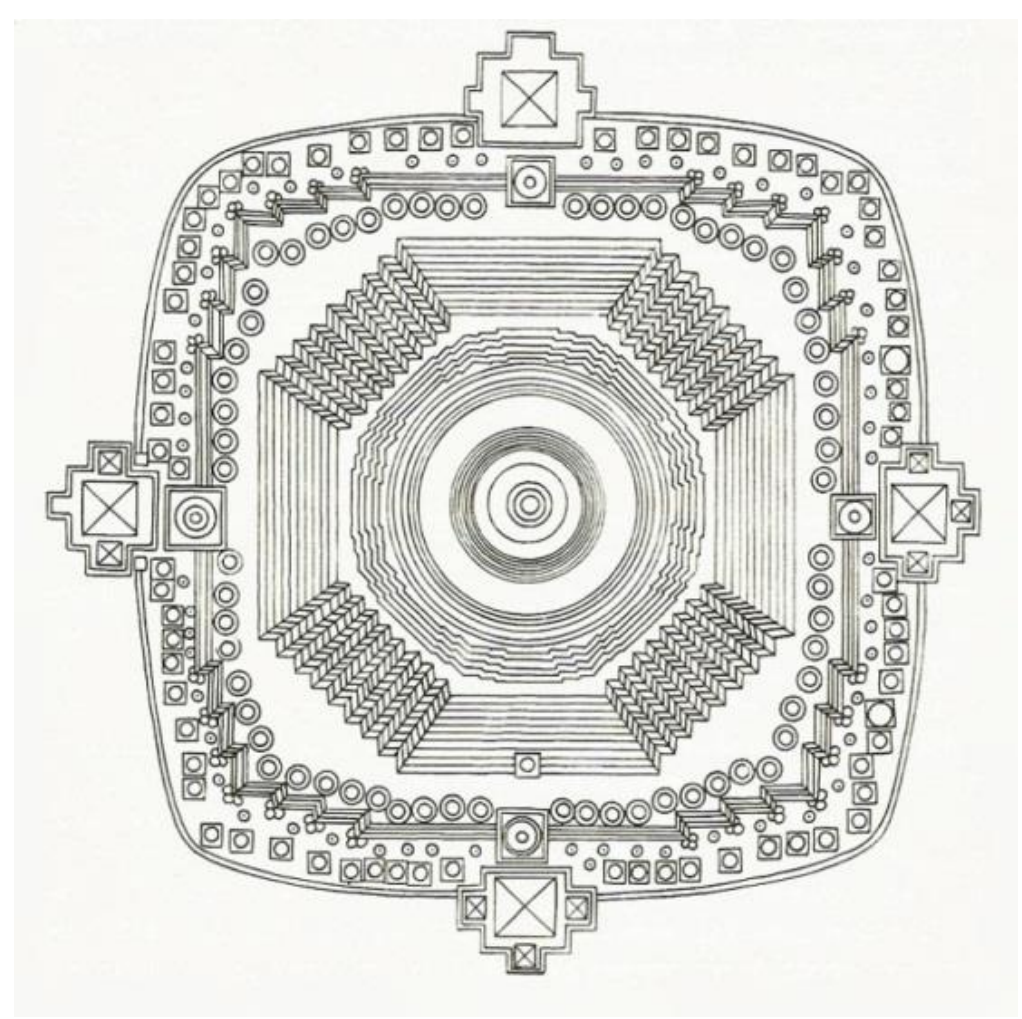

Figure.11 Top View of Myanmar's Shwedagon Stupa (Source: www.shwedagonpagoda.com)

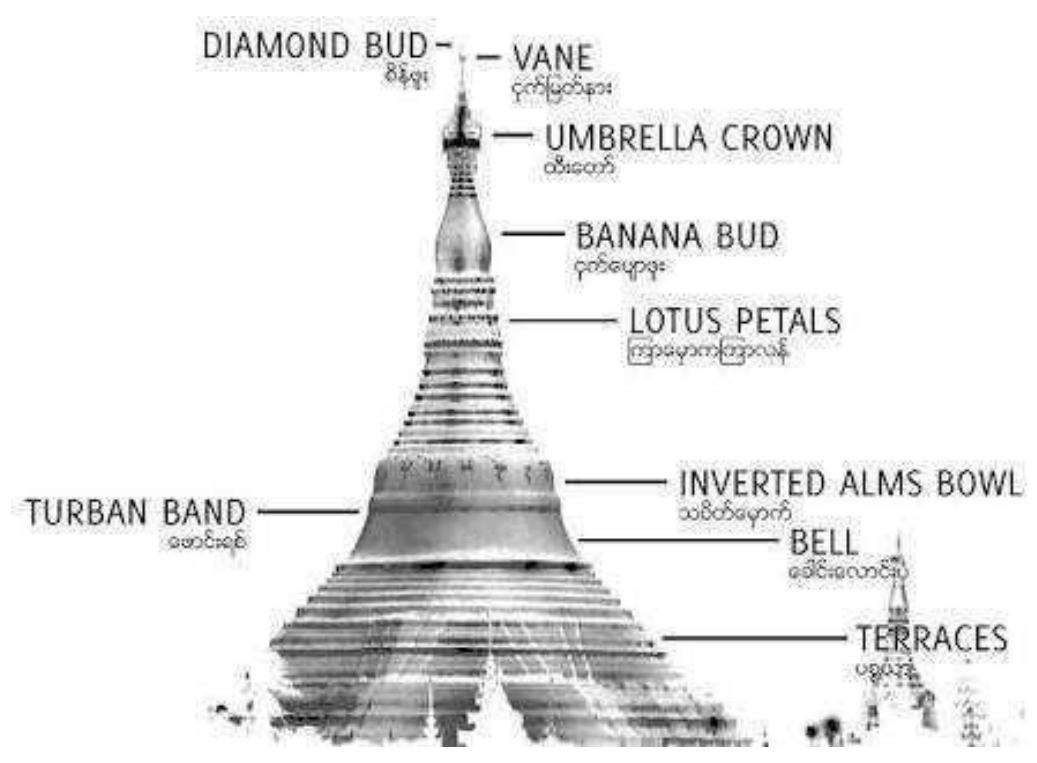

Figure. 12 Elements of the Shwedagon Stupa in Myanmar (Source: www.steemit.com)

It seems that the original Shwedagon stupa in Myanmar is fully adopted, but in its implementation in the Padepokan Dhammadipa Ārāma complex, the stupa is placed on the second-floor mass, with the result that it seems to be the head of the building, and on the first-floor mass, the room functions for activities. Hence, the Patirupaka or the replica functions as a flat roof decorated with a stupa. 
The typo-morphological identification of the elements of the Shwedagon Stupa consists of:

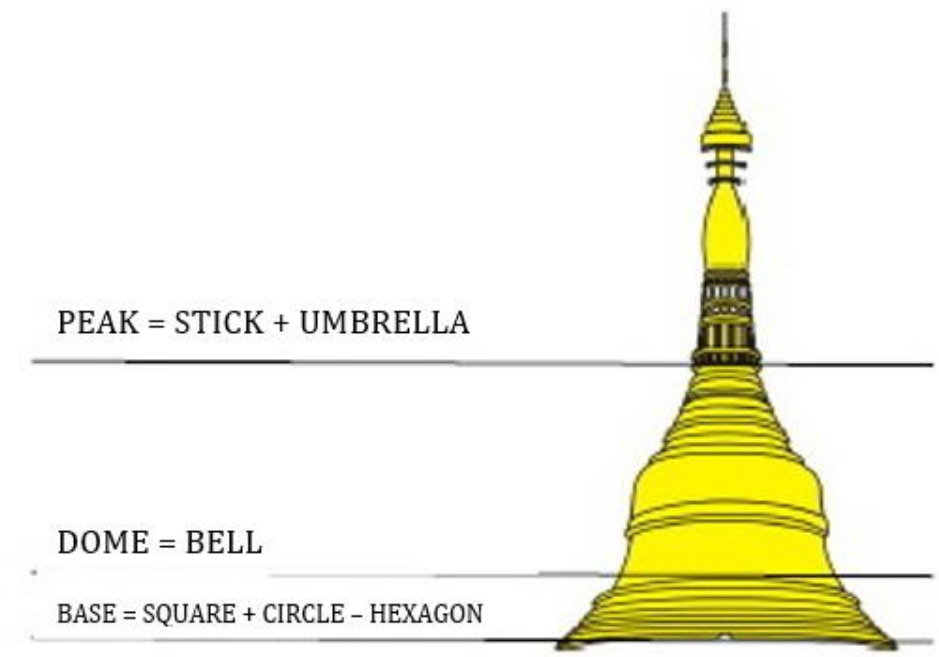

Figure. 13 Identification of Elemental Morphology of the Shwedagon Stupa in Myanmar (Source: www.steemit.com)

1. The stupa base is in the form of a stepped square that is octagonal, and the topmost base has a circular shape.

2. Stupa's body resembles a bell.

3. The peak of the Stupa is Chattravali which is usually shaped and functions as an umbrella. The umbrella is an expression of cosmic power. Back to the early the initial function of the stupa to store relics of saints or kings, this umbrella element also tries to show the king's existence, whether he is a king of all kings or a king of the heavenly kingdom.

The following table will describe the identification of typo-morphology based on historical studies of the construction of a stupa.

Table 1. Study of Stupa Typo-morphology based on the History of the Construction of a Stupa

\begin{tabular}{|c|c|c|c|c|}
\hline $\begin{array}{c}\text { STUPA } \\
\text { CONSTRUCTIO } \\
\text { N ELEMENTS }\end{array}$ & $\begin{array}{c}\text { STUPA } \\
\text { ARCHITECTU } \\
\text { RE SECTION }\end{array}$ & $\begin{array}{c}\text { STUPA } \\
\text { ELEMEN } \\
\text { T SHAPE }\end{array}$ & ELEMENT PART & $\begin{array}{c}\text { PATIRUPAK } \\
\text { A/ REPLICA } \\
\text { OF THE } \\
\text { SHWEDAGON } \\
\text { DHAMMADIP } \\
\text { A ĀRĀMA } \\
\text { STUPA }\end{array}$ \\
\hline \multirow[t]{2}{*}{ ROBE FOLD } & \multirow{2}{*}{$\begin{array}{l}\text { BOTTOM OF } \\
\text { THE BUILDING }\end{array}$} & \multirow{2}{*}{ BASE } & SQUARE & X \\
\hline & & & ROUND/CIRCLE & $x$ \\
\hline
\end{tabular}




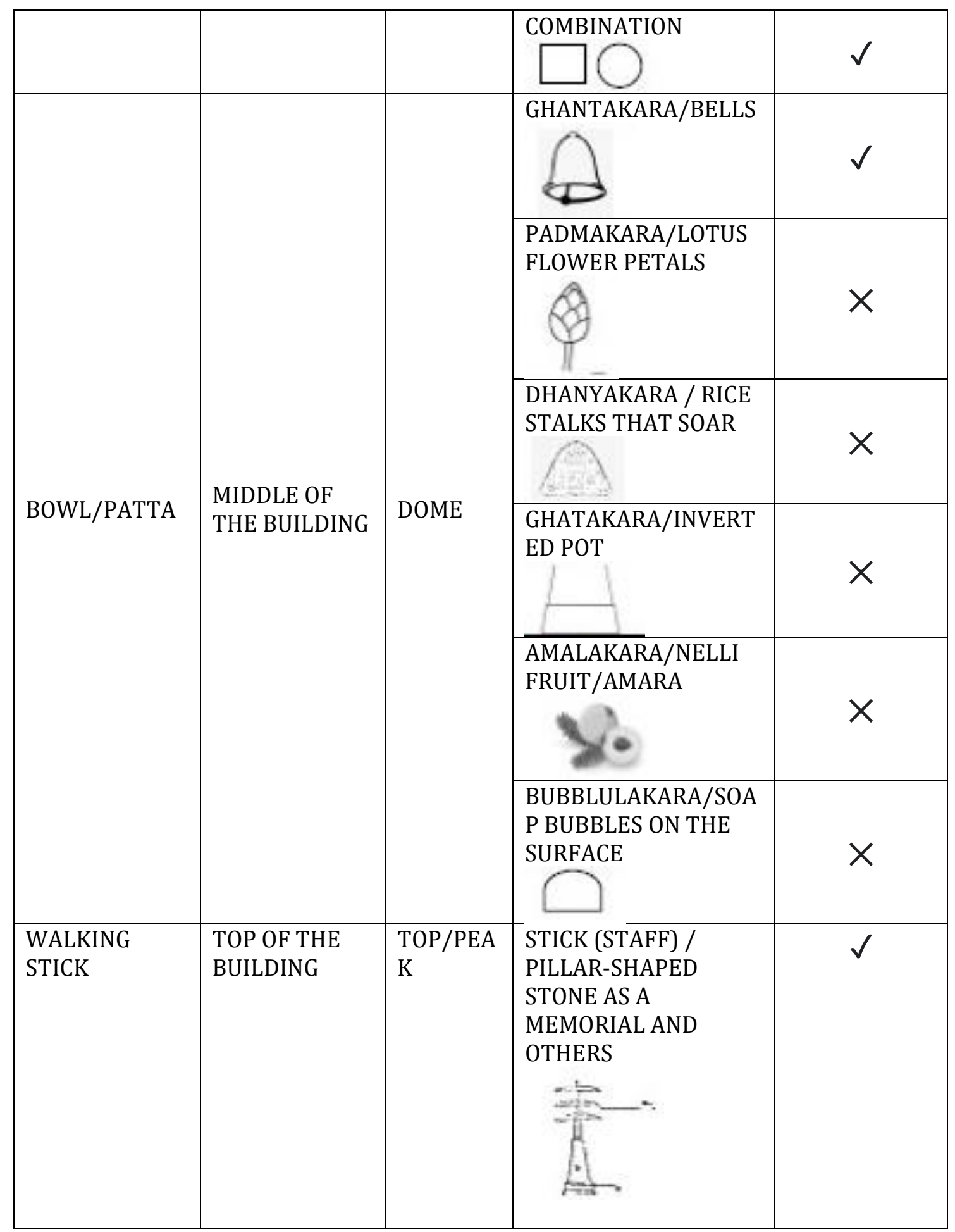

(Source: Personal Data)

Typo-morphological analysis of the Patirupaka Shwedagon Stupa at Padepokan Dhammadipa Āräma Malang in terms of the function of the building mass

Based on its nature, stupa architecture can be divided into three types: monumental stupas, stupa that has the nature of a building (can be entered), and ornamental stupas. 
At first, all stupas were monumental. This is based on the function of the original stupa. In further developments, the shape of the stupa is made as to the cover of a vihāra or cetiya building and has function as an ornamental element in Buddhist religious buildings as an architectural identity for worship.

The unique shape of the stupa at Patirupaka Swhedagon at Padepokan Dhammadipa Ārāma consists of 2 floors, where the first floor has interior space, and the upper floor is a replica that is not solid, which can be used as relic storage. However, it seems as if the upper floor is only a roof ornament from the aspect of form

\section{Conclusion}

Based on various analyses discussed in the previous section, it can be concluded that the stupa building can be used as a place of activity and functions as a religious expression. Therefore, no shift in meaning occurs, but in terms of form, an octagonal shape appears as a gradation of the combined shape of the square and circle shapes. Developments and changes occur in the form of mass even though the function of the stupa is still vital, both as the center orientation of the micro cosmos and macro cosmos. The developments and changes are that the stupa in the Dhammasāla building is monumental, and the replica is a building with a mass of 2 floors. As a result, different expressions and variations appear both in the shape and mass of the building and activities.

For further research, it is recommended to study typo-morphology based on the original stupa parts and their meanings, and it can be developed further based on the typology of the Pañca Bhūta symbol. Examining Paul Mus's theory of 5 typologies from the base, dome, and the peak is also needed.

\section{Acknowledgment}

We would like to thank the Padepokan Dhammadipa Ārāma for collecting data on the object of the research study. We are grateful to Ven. Dharmasurya Bhumi Mahathera for the loan of literature books and discussions on previous research and Ven. Thitacarini for the opportunity to contribute to the Smaratungga: Journal of Education and Buddhist Studies (SJEBS). We also wish to thank Dhamma Brothers and other parties who cannot be mentioned one by one who has supported the research process and the report writing.

\section{Funding}

This research was supported by the Internal Fund of the Research and Community Service Institution of Maranatha Christian University in 2020.

\section{References}

Anonymous. Buddhist Worship. Srilanka.

Bandaranayake, Senake. 1974. Sinhalese Monastic Architecture, Studies in South Asian Culture Volume IV. Leiden, E.J Brill.

Barker, Chris. 2004. Cultural Studies: Teori \& Praktik. Yogyakarta: Kreasi Wacana.

Ching, Francis D.K. 1996. Arsitektur, Bentuk, Ruang dan Susunannya. Erlangga: Jakarta. 
Diputhera, Oka. 1979. Maha Parinibbana Sutta: Proyek Pengadaan Kitab Suci Buddha. Jakarta.

Fisher, Robert. 1993. Buddhist, Art, and Architecture. London: Thames and Hudson Ltd.

Hall, Stuart. 1997. Representation: Cultural Representation and Signifying Practises. London: Sage

Hameed, H. (2020). Quantitative and qualitative research methods: Considerations and issues in qualitative research. The Maldives National Journal of Research, 8(1), 8-17. https://www.skillsyouneed.com/learn/quantitative-andqualitative.html

http://filsafat.kompasiana.com/2010/01/30/agama-buddha-bukan-berhala64704.html accessed on July 29, 2020

http://jordikurni.wordpress.com accessed on July 29, 2020

http://digilib.uinsby.ac.id/907/3/bab\%202.pdfhttp://digilib.uinsby.ac.id/907/3/ bab\%202.pdf accessed on August 11, 2020

http://andcisonline.blogspot.com/2012/05/loporan-studi-komparatif-kepadepokan.html accessed on August 11, 2020

https://buddhazine.com/melihat-padepokan-dhammadipa-ārāma-batu-malang/ accessed on August 11, 2020.

Mangunwijaya, Y.B.1988. Wastu Citra. Jakarta: PT Gramedia.

Priastana, Dhammasukha Jo. 1994. Pokok-pokok Dasar Mahayana. Jakarta:

Yasodhara Puteri.

Sari, Yenni Prisca. 2013. Perkembangan Padepokan Dhammadipa Ārāma di

Kota Batu 1971-2007. Thesis, History Education Study Program, Department of History, Faculty of Social Sciences, State University of Malang.

Sangha Mahayana Indonesia. 1991. Kriteria Rumah Ibadah Umat Buddha Mahayana Indonesia, Cetakan I. Jakarta: Majelis Agama Buddha Indonesia.

Subalaratano, Uttamo. Puja. Sangha Theravada Indonesia.

Sylvia Fraser-Lu. Donald M. Stadtner, Buddhist Art of Myanmar, Asia Society Museum, 2015.

Tim Penyusun. 1998. Buku Pelajaran Agama Buddha Sekolah Menengah Tingkat Atas Kelas I. Surabaya: Paramita.

U Win Maung, The Ancestral Stupas of Shwedagon, International Buddhist Conference, Brastagi, Indonesia, 2010.

Wright, Frank Llyod. 1992. Between Principle and Form. New York: Van Nostrand Reinhold.

www.archdaily.com accessed on June 25, 2020.

www.x.furuhitto,st,mt.staffsite.com accessed on July 8, 2020.

www.samaggiphala.or.id accessed on July 8, 2020. 